\title{
Inflammatory cytokines regulate endothelial cell survival and tissue repair functions via NF- $\mathrm{KB}$ signaling
}

This article was published in the following Dove Press journal:

Journal of Inflammation Research

14 September 2011

Number of times this article has been viewed

\author{
Nobuhiro Kanaji' \\ Tadashi Sato ${ }^{2}$ \\ Amy Nelson ${ }^{3}$ \\ Xingqi Wang ${ }^{3}$ \\ Yingji $\mathrm{Li}^{4}$ \\ Miok $\mathrm{Kim}^{5}$ \\ Masanori Nakanishi ${ }^{6}$ \\ Hesham Basma ${ }^{3}$ \\ Joel Michalski ${ }^{3}$ \\ Maha Farid ${ }^{3}$ \\ Michael Chandler ${ }^{3}$ \\ William Pease ${ }^{3}$ \\ Amol Patil ${ }^{3}$ \\ Stephen I Rennard ${ }^{3}$ \\ Xiangde Liu $^{3}$ \\ 'Division of Hematology, \\ Rheumatology and Respiratory \\ Medicine, Kagawa University, Kagawa, \\ Japan; ${ }^{2}$ Department of Respiratory \\ Medicine, Juntendo University School \\ of Medicine, Tokyo, Japan; ${ }^{3}$ Pulmonary \\ and Critical Care Medicine, University \\ of Nebraska Medical Center, \\ Omaha, Nebraska; ${ }^{4}$ Department of \\ Hygiene and Public Health, Nippon \\ Medical School, Tokyo, Japan; ${ }^{5}$ Third \\ Department of Internal Medicine, \\ Wakayama Medical University \\ School of Medicine, Wakayama, Japan; \\ ${ }^{6}$ Department of Internal Medicine, \\ Jeju Medical College, Jeju, Republic \\ of Korea
}

Correspondence: Xiangde Liu University of Nebraska Medical Center, 985910 Nebraska Medical Center, Omaha, Nebraska 68198-5910, USA

$\mathrm{Tel}+\mathrm{I} 402559-7586$

$\mathrm{Fax}+\mathrm{I} 402$ 559-4878

Email xdliu@unmc.edu

\begin{abstract}
Inflammation contributes to the development of fibrotic and malignant diseases. We assessed the ability of inflammatory cytokines to modulate endothelial cell survival and functions related to tissue repair/remodeling. Treatment with interleukin (IL)-1 $\beta$ or tumor necrosis factor (TNF)- $\alpha(2 \mathrm{ng} / \mathrm{mL})$ led to human pulmonary artery endothelial cells becoming spindle-shaped fibroblast-like cells. However, immunoblot and DNA microarray showed no change in most endothelial and mesenchymal markers. In the presence of IL- $1 \beta$ or TNF- $\alpha$, cells were resistant to apoptosis induced by deprivation of serum and growth factor, and were more migratory. In addition, cells treated with IL- $1 \beta$ or TNF- $\alpha$ contracted collagen gels more robustly. In contrast, transforming growth factor- $\beta 1$ did not induce these responses. RNA interference targeting nuclear factor (NF)- $\kappa B$ p 65 blocked the effects of IL-1 $\beta$ or TNF- $\alpha$ on cell morphologic change, survival, migration, and collagen gel contraction. These results suggest that endothelial cells may contribute to tissue repair/remodeling via the NF- $\kappa B$ signaling in a milieu of airway inflammation.
\end{abstract}

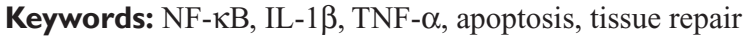

\section{Introduction}

Airway inflammation is believed to play an important role in the development of many diseases. Endothelial cells are essential in normal development and angiogenesis and also play an important role in inflammatory responses. In this regard, upregulation of adhesion molecules on endothelial cells causes leukocytes to attach to the endothelium at sites of injuries and infection. ${ }^{1}$ The inflammatory cytokines interleukin (IL)- $1 \beta$ and tumor necrosis factor (TNF)- $\alpha$ are key players that regulate endothelial cell responses following inflammation. ${ }^{1}$ These cytokines can also contribute to development of tissue remodeling and fibrosis by modulating endothelial cell functions as demonstrated in dermal microvascular endothelial cells. ${ }^{2}$ These tissue repair/remodeling functions are akin to those of fibroblasts or myofibroblasts.

Cell migration and contraction of extracellular matrix are often used as in vitro models of tissue repair/remodeling. It is known that transforming growth factor (TGF)- $\beta 1$ stimulates fibroblast-mediated collagen gel contraction ${ }^{3}$ and chemotaxis. ${ }^{4}$ On the other hand, IL-1 $\beta$ and TNF- $\alpha$ inhibit fibroblast-mediated collagen gel contraction through the induction of nitric oxide and PGE $2,{ }^{5}$ both of which also inhibit chemotaxis. ${ }^{6,7}$ However, the effect of TGF- $\beta 1$, IL- $1 \beta$, or TNF- $\alpha$ on pulmonary endothelial cell-mediated tissue repair has not been studied.

Nuclear factor (NF)- $\kappa \mathrm{B}$ is a transcription factor that mediates downstream signaling of IL-1 $\beta$ and TNF- $\alpha$ and has major roles in inflammation, cell proliferation, 
differentiation, apoptosis, and cell survival. ${ }^{1,8,9} \mathrm{NF}-\kappa \mathrm{B}$ is also involved in several critical functions of endothelial cells such as angiogenesis. ${ }^{10}$ However, the role of NF- $\kappa \mathrm{B}$ in regulating tissue repair functions mediated by endothelial cells has not been reported.

The current study was, therefore, designed to investigate the effect of inflammatory cytokines (IL-1 $\beta$ and TNF- $\alpha$ ) and TGF- $\beta 1$ on human pulmonary artery endothelial cell (HPAEC) mediated tissue repair and remodeling. In addition, we assessed the role of NF- $\mathrm{BB}$ in modulating alteration of cell morphology, survival, and tissue repair functions in response to stimulation by IL- $1 \beta$ and TNF- $\alpha$.

\section{Materials and methods Reagents}

Recombinant human IL- $1 \beta$, TNF- $\alpha$, and TGF- $\beta 1$ were purchased from R\&D systems (Minneapolis, MN). FITCphalloidin and curcumin were purchased from SigmaAldrich (St. Louis, MO). HRP-conjugated anti-rabbit IgG antibody was purchased from Rockland (Gilbertsville, PA). The small interference RNA (siRNA) targeting p65 and nontargeting control siRNA were purchased from Dharmacon (Lafayette, CO; siGENOME SMARTpool, M-003533-02 and D-001206-13, respectively).

\section{Cell culture and treatment}

HPAEC were purchased from Clonetics, Lonza (Walkersville, $\mathrm{MD}$ ), and maintained in endothelial cell growth medium (EGM-2, Lonza) which contains serum and growth factors. Cells were treated with IL-1 $\beta$ ( 2 ng/mL), TNF- $\alpha(2 \mathrm{ng} / \mathrm{mL})$, or TGF- $\beta 1(2 \mathrm{ng} / \mathrm{mL})$ in a 1:1 mixture EGM-2 to endothelial cell basal medium (EBM-2, which contains no serum or growth factors) resulting in a final concentration of $1 \%$ fetal bovine serum (FBS) (named as 1:1 EBM) for 2 days. Concentrations of the cytokines were chosen based on preliminary studies conducted from 1 to $5 \mathrm{ng} / \mathrm{mL}$. To induce apoptosis, cells were incubated in EBM-2, which is without any growth factors or serum, for 5 days. In some experiments, cells were pretreated with curcumin $(10 \mu \mathrm{M})$, a potent NF- $\kappa \mathrm{B}$ inhibitor, for 1 hour prior to addition of cytokines. The A549 alveolar epithelial-like cell line and HFL-1 human fetal lung fibroblasts were purchased from ATTC and maintained in DMEM with $10 \%$ FBS. A549 cells were treated with $2 \mathrm{ng} / \mathrm{mL}$ of TGF- $\beta 1$ in DMEM with $0.5 \%$ FBS for 2 days.

\section{Cell length measurement}

Cells were then fixed and stained with PROTOCOL HEMA3 solutions (Fisher Scientific Company L.L.C.,
Kalamazoo, MI). A Nikon Eclipse TE300 microscope (Nikon, Tokyo, Japan) equipped with a DP71 digital camera and DP Controller software (Olympus, Tokyo, Japan) was used to take photomicrographs. To quantify cell morphologic change, cell length was measured using the ImageJ $1.33 \mathrm{u}$ software, NIH. A mean of 50 cells for each condition was measured. Data are presented as percent compared with mean of control.

\section{Visualization of F-actin}

After treatment with cytokines, cells were fixed with $3.7 \%$ formaldehyde and permeabilized with $0.5 \%$ Triton X-100 in PBS for 15 minutes. After washing with PBS, cells were blocked with $5 \%$ bovine serum albumin for 1 hour, and then incubated with FITC-phalloidin $(1 \mu \mathrm{g} / \mathrm{mL})$ at room temperature for 1 hour.

\section{RNA preparation and DNA microarray}

After cells were treated with cytokines $(2 \mathrm{ng} / \mathrm{mL})$ for 2 days, total RNA was isolated by TRIzol (Invitrogen, Carlsbad, CA, USA) according to the manufacture's protocol, and the total amount was quantified spectrophometrically (Shimadzu Scientific Instruments, Columbia, MD). The OneArray ${ }^{\mathrm{TM}}$ Whole Genome DNA microarray (Phalanx Biotech, Palo Alto, CA) was used for comparing gene expression profiles between cells treated with cytokines and control without cytokines. Labeling of cDNA, hybridization of labeled cDNA to genome probes, and scanning were performed according to the manufacturer's instructions. Every array was performed in triplicate. Data are presented as a fold change compared with control.

\section{NF- $\kappa B$ gene silencing}

Cells were transfected with siRNA targeting NF- $\kappa B$ p 65 or a nontargeting control siRNA (final concentration of siRNA was $50 \mathrm{nM}$ ) in OptiMEM I (Invitrogen, Carlsbad, CA) using Lipofectamine 2000 (Invitrogen) (day 0). After 8 hours, media were changed to complete medium. On day 2, cells were treated with cytokines for an additional 2 to 4 days as indicated.

\section{Collagen gel contraction assay}

Collagen gel contraction assay was performed by a modification of a previously published method. ${ }^{3}$ Briefly, native type I collagen gels were prepared by mixing a solution of rat tail tendon collagen (approximately $3 \mathrm{mg} / \mathrm{mL}$ ), EGM-2 or DMEM (for HPAEC or HFL-1, respectively) and cell suspension so that the final mixture resulted in $0.75 \mathrm{mg} / \mathrm{mL}$ collagen and $3 \times 10^{5}$ cells $/ \mathrm{mL}$. A $500 \mu \mathrm{L}$ aliquot of the resulting solution was then cast into each well of a 24 -well 
culture plate and allowed to polymerize. After gelation was completed, in about 20 minutes at room temperature, the gels were gently released into 60-mm dishes ( 3 gels in each dish) containing $5 \mathrm{~mL}$ of 1:1 EBM or serum-free DMEM (for HPAEC or HFL-1, respectively) with or without cytokines and incubated at $37^{\circ} \mathrm{C}$ for 4 days. Gel size was measured with the Optomax V image analyzer (Optomax, Burlington, MA). Data are expressed as the percentage of gel area compared with the original gel size.

\section{Wound closure assay}

Cells were pretreated with or without cytokines $(2 \mathrm{ng} / \mathrm{mL})$ in a 1:1 EBM for 2 days. Fixed widths of linear wounds were then created using a cell scraper (Corning Inc., Corning, NY), and the remaining cells were incubated in a 1:4 mixture EGM-2 to EBM-2 for 16 hours in the presence or absence of cytokines $(2 \mathrm{ng} / \mathrm{mL})$. Cells were then fixed, stained, and photographed. To quantify cell migration, a grid was lined on each image at 0 and 16 hours after wounding by Photoshop Elements 2.0 software (Adobe Systems Inc., San Jose, CA) to make 1064 tiny squares. The number of squares with migrated cells was counted. Three fields for each condition were quantified. Data are presented as percentage of squares occupied by migrated cells after wounding.

\section{Profiling of DNA content by flow cytometry}

Nearly confluent cells were treated with or without cytokines ( $2 \mathrm{ng} / \mathrm{mL}$ ) in EBM-2 only (serum- and growth factor-free medium) for 2 days. Both attached and floating cells were collected and fixed with cold $70 \%$ ethanol in PBS at $4{ }^{\circ} \mathrm{C}$ for 30 minutes. Cells were then pelleted by centrifugation and resuspended in the staining solution $(50 \mu \mathrm{g}$ propidium iodide, $100 \mu \mathrm{g}$ RNase A in $1 \mathrm{~mL}$ PBS). After 1 hour staining at $4^{\circ} \mathrm{C}$, flow cytometric DNA content profiling was performed as previously described. ${ }^{3}$

\section{Statistical analysis}

Data are expressed as mean \pm standard deviation (SD). An unpaired 2-tailed Student's $t$-test was used for single comparisons. $P$ values $<0.05$ were considered as statistically significant.

\section{Results}

\section{Effect of cytokines on cell morphology and endothelial/mesenchymal cell markers}

Under control conditions, HPAECs grow as a monolayer of polygonal shaped cells. In response to IL-1 $1 \beta$ or TNF- $\alpha$,
HPAECs undergo morphologic alteration. Typically, the cells became elongated and spindle shaped and appeared as fibroblast-like cells (Figure 1A). The elongation of the cells was statistically significant (Figure $1 \mathrm{~B}, P<0.05$ ). The combination of IL- $1 \beta$ and TNF- $\alpha$ together resulted in a greater alteration in cell morphology, which was readily observed morphologically (Figure 1A) and confirmed by measurement of cell length (Figure 1B, $P<0.05$ compared with either IL- $1 \beta$ or TNF- $\alpha$ alone). TGF- $\beta 1$ ( $2 \mathrm{ng} / \mathrm{mL}$ ) changed cell morphology and cell length in A549 alveolar epithelial cells (Figures 1A and B) as reported previously. ${ }^{11,12}$ In contrast, HPAEC morphology was not altered by TGF- $\beta 1$ at the concentration used for A549 cells ( $2 \mathrm{ng} / \mathrm{mL}$, Figures $1 \mathrm{~A}$ and B). Furthermore, even a higher concentration of TGF- $\beta 1$ (20 ng/ $\mathrm{mL}$ ) did not affect HPAEC morphology, and TGF- $\beta 1$ did not affect the HPAEC morphologic change induced by IL-1 $\beta$ or TNF- $\alpha$ (data not shown). Consistent with the morphologic change, either IL-1 $\beta$ or TNF- $\alpha$, but not TGF- $\beta 1$, induced F-actin polymerization as visualized by phalloidin binding histochemistry (Figure 1C). A similar effect of IL-1 $\beta$ and TNF- $\alpha$ on alteration of cell morphology was observed in human umbilical vein endothelial cells (HUVEC) obtained from Clonetics (data not shown).

To investigate the reversibility of the spindle-shaped HPAEC morphology, following a 2-day treatment with IL-1 $\beta$ or TNF- $\alpha$ that induced morphologic change, the cells were incubated in EGM-2 without cytokines. As a result, spindle-shaped cell morphology was reverted to polygonal shape completely within 4 days after removal of cytokines (data not shown).

We next explored if cytokines affect expression of endothelial and mesenchymal markers. Unexpectedly, none of the cytokines tested in the current study affected the expression of VE- and $\mathrm{N}$-cadherins, vimentin, or $\alpha$-smooth muscle actin by immunoblot (data not shown). To further investigate a wider range of endothelial and mesenchymal cell markers, we performed DNA microarrays (Table 1). Using this method, e-selectin gene was observed to be greatly increased by IL-1 $\beta$ (8.25-fold) as previously reported. ${ }^{13}$ However, other endothelial cell and adhesion markers were unchanged despite the fibroblast-like morphologic appearance induced by IL- $1 \beta$ or TNF- $\alpha$. Similarly, mesenchymal markers were not increased by these cytokines except for a slight increase in fibronectin 1 (1.88-fold by IL-1 $\beta$ ).

To investigate the effect of longer exposure to cytokines, we treated the cells with IL-1 $\beta$ or TNF- $\alpha$ up to 14 days. Interestingly, cell morphologic change was not enhanced by more than 2 days of treatment. In addition, 
A

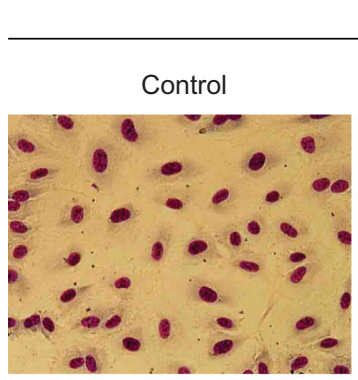

TNF- $\alpha$

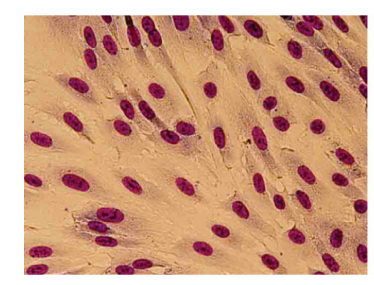

B

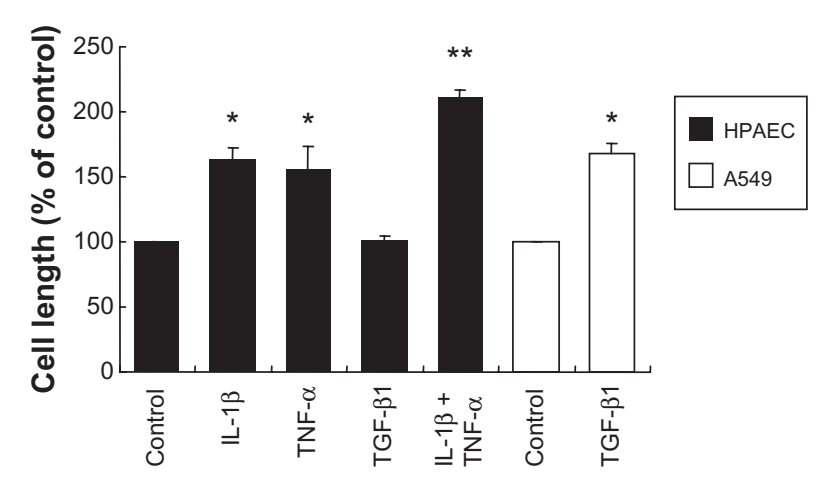

HPAEC

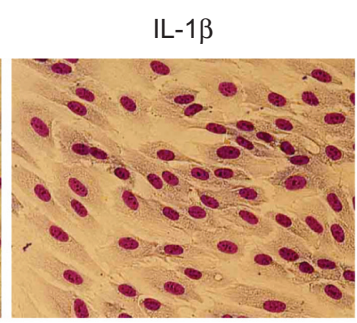

TGF- $\beta 1$

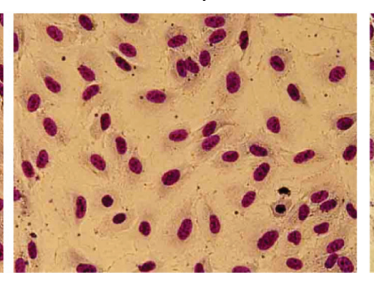

$\mathrm{IL}-1 \beta+\mathrm{TNF}-\alpha$

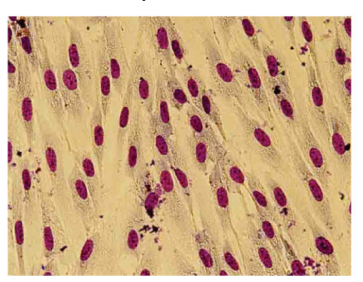

C

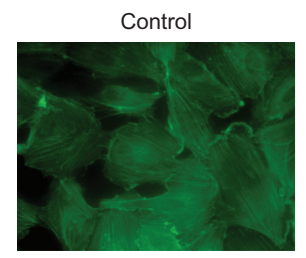

TNF- $\alpha$

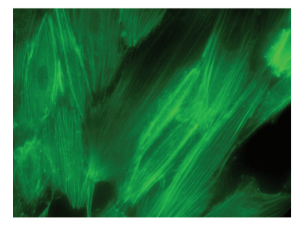

A549

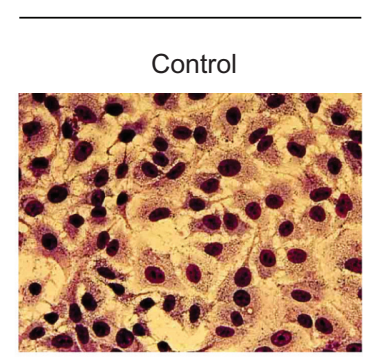

TGF- $\beta 1$

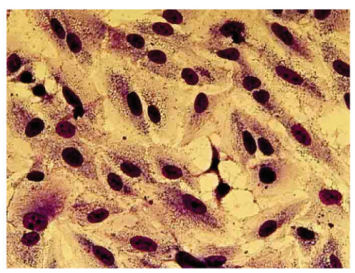

IL-1 $\beta$

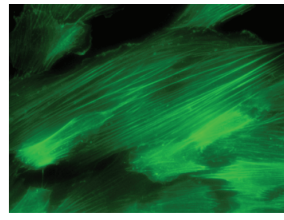

TGF- $\beta 1$

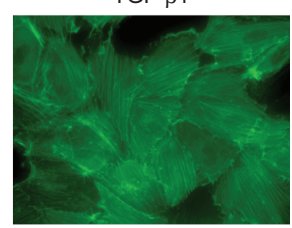

Figure I Effect of IL-I $\beta$, TNF- $\alpha$ and TGF- $\beta$ I on cell morphology, actin cytoskeletal arrangement. HPAECs and A549 alveolar epithelial cells were treated with 2 ng/mL of IL-I $\beta$, TNF- $\alpha$, or TGF- $\beta$ I alone or in combination for 2 days. A) Cell morphology. Photographs were taken after Diff Quick staining (original magnification $\times 400$ ). B) Cell size. Values are means \pm SD of 3 separate experiments. C) Actin microfilament polymerization. F-actin was visualized by FITC-phalloidin (original magnification $\times 600$ ). Notes: $* P<0.05$ compared with control; $* * P<0.05$ compared with cells treated with IL-I $\beta$.

endothelial and mesenchymal markers including VE- and $\mathrm{N}$-cadherins and vimentin were still not affected (data not shown).

\section{Effect of IL-I $\beta$ and TNF- $\alpha$ on cell survival in the absence of serum and growth factors}

HPAECs were cultured to subconfluence in EGM-2

(Figure 2A, before treatment panel). When the cells were subsequently cultured in EBM-2 without serum and growth factors without the addition of cytokines, the majority of the cells detached and underwent apoptosis within 5 days (Figure 2A, Control panel). In the presence of IL-1 $\beta$ or TNF- $\alpha$, but not in the presence of TGF- $\beta 1$, however, most of the cells remained alive and underwent morphologic change in EBM-2 (Figure 2A). Interestingly, the few cells that survived in control conditions or in the presence of TGF- $\beta 1$ also had an elongated fibroblast-like appearance.
To evaluate if the detached cells were undergoing apoptosis, DNA content was profiled by a FACS analysis using propidium iodide staining (Figure 2B). Consistent with the microscopic observations, an average of $31.0 \% \pm 4.7 \%$ of the cells underwent apoptosis after 2 days in the basal medium without cytokines (Figure 2B, insert). In contrast, apoptosis was significantly reduced by either IL- $1 \beta(8.0 \% \pm 4.2 \%$, $P<0.01)$ or TNF- $\alpha(5.2 \% \pm 1.6 \%, P<0.01)$, but not by TGF- $\beta 1(32.9 \% \pm 3.3 \%, P>0.05)$.

\section{Effect of IL-I $\beta$ and TNF- $\alpha$ on tissue repair functions of HPAECs}

To investigate if the inflammatory cytokines could affect HPAEC tissue repair functions, wound closure and collagen gel contraction assays were performed. Either IL-1 $\beta$ or TNF- $\alpha$ alone stimulated cell migration in the wound closure assay (Figures $3 \mathrm{~A}$ and B). Wound closure $(33.3 \pm 6.4 \%$ in 
Table I Gene expression of endothelial and mesenchymal markers

\begin{tabular}{lcll}
\hline & IL-I $\beta$ & TNF- $\alpha$ & TGF- $\beta$ I \\
\hline Endothelial/cell junctional & markers & & \\
VE-cadherin & 0.86 & 0.97 & 1.02 \\
TIEI & 0.71 & 0.81 & 0.83 \\
TIE2 & 1.21 & 0.96 & 1.02 \\
VEGFR-I & 0.97 & 0.60 & 0.88 \\
VEGFR-2 (FIk-I) & 1.12 & 1.03 & 0.99 \\
PECAMI (CD3I) & 1.06 & 1.00 & 1.36 \\
VWF & 0.75 & 0.83 & 1.27 \\
E-selectin & 8.25 & 1.58 & 0.75 \\
Claudin-5 & 0.96 & 1.25 & $0.8 \mathrm{I}$ \\
$\beta$-catenin & 0.76 & 0.74 & 0.86 \\
ZO-I & 0.71 & 0.76 & 0.85 \\
Mesenchymal markers & & & \\
Vimentin & 0.75 & 0.85 & 1.16 \\
$\alpha-S M A$ & 1.41 & 0.87 & 1.11 \\
N-cadherin & 0.86 & 0.98 & 0.69 \\
Collagen I & 0.94 & 1.06 & 0.91 \\
Fibronectin I & $\mathrm{I} .88$ & 1.25 & 0.99 \\
\hline
\end{tabular}

Notes: Values are expressed as fold change compared to control; some genes which expressions are very low in all conditions are not shown, including collagen III and fibroblast specific protein-I.

control) was increased to $71.6 \% \pm 11.9 \%$ or $83.8 \% \pm 12.2 \%$ by IL- $1 \beta$ or TNF- $\alpha$, respectively $(P<0.05$, Figure $3 \mathrm{~B})$. The two in combination did not further enhance cell migration compared with either cytokine alone. In contrast, TGF- $\beta 1$ did not affect cell migration.

Collagen gel contraction assay was performed to assess the ability of cells to remodel extracellular matrix. Under control conditions, normal HPAECs were able to contract native type I collagen gels when the cells were cast into the gels. Gel size decreased gradually and reached $69.9 \% \pm 8.1 \%$ of initial size on day 4 (Figure 3C). Gel contraction was significantly augmented to $50.8 \% \pm 8.1 \%$ and $47.7 \% \pm 12.5 \%$ of initial size on day 4 by IL- $1 \beta$ or TNF- $\alpha$, respectively $(P<0.05)$. In contrast, TGF- $\beta 1$ did not affect gel contraction $(71.9 \% \pm 7.7 \%, P>0.05)$, although TGF- $\beta 1$ augmented human lung fibroblast-mediated collagen gel contraction (Figure 3C), which is a well known effect of TGF- $\beta 1 .^{3}$

\section{Role of NF- $\kappa B$ signaling pathway in mediating IL-I $\beta$ or TNF- $\alpha$ effects}

To investigate the role of NF- $\mathrm{KB}$ in mediating the effects of IL- $1 \beta$ or TNF- $\alpha$ on HPAEC, we used both a pharmacologic inhibitor and an RNA interference strategy.

\section{Pharmacologic inhibition}

Curcumin, an inhibitor of NF- $\mathrm{KB}$ signaling, significantly blocked not only the cell morphologic change induced by IL- $1 \beta$ or TNF- $\alpha$ (Figures 4 A and B), but also the increased cell survival observed in the presence of IL- $1 \beta$ or TNF- $\alpha$ (Figure 4C).

\section{RNA interference}

Introduction of an siRNA targeting p65 into HPAECs resulted in remarkable suppression of p65 protein level assessed by immunoblot (data not shown). Similar to the curcumin effect, suppression of p65 by siRNA not only prevented cell morphologic change in response to IL-1 $\beta$ and TNF- $\alpha$ (Figures 5A and B), but also blocked the inhibition of apoptosis by IL-1 $\beta$ or TNF- $\alpha$ (Figure 5 C). F-actin polymerization induced by IL- $1 \beta$ or TNF- $\alpha$ was also abolished by p65-siRNA (Figure 6A). In addition, cells lacking p65 were able to migrate and contract collagen gels under control conditions, but could not respond to the stimulation of IL- $1 \beta$ or TNF- $\alpha$, while cells transfected with the nontargeting control siRNA responded to either cytokine significantly (Figures 6B-D).

\section{Discussion}

The present study demonstrates that the inflammatory cytokines IL-1 $\beta$ and TNF- $\alpha$ induce HPAEC morphologic change which resembles that of fibroblasts and render the cells resistant to apoptosis following growth factor withdrawal. In addition, IL- $1 \beta$ and TNF- $\alpha$ stimulated HPAEC migration and augmented collagen gel contraction by HPAEC through the NF- $\mathrm{KB}$ signaling.

There is emerging evidence supporting the concept that endothelial cells undergo mesenchymal transition, that is, endothelial-mesenchymal transition (EndMT). Through this mechanism, endothelial cells have been suggested to play a role in normal development and may contribute to tissue fibrosis., ${ }^{214-16}$ EndMT is generally associated with the acquisition of a fibroblast-like morphologic shape, loss of endothelial/cell adhesion markers and acquisition of mesenchymal markers. ${ }^{14,15}$ In this regard, the current study demonstrated that IL-1 $\beta$ and TNF- $\alpha$ induced fibroblastlike morphologic change in both HPAEC and HUVEC. Interestingly, however, most of the endothelial and mesenchymal cell markers were unchanged by these cytokines. Although EndMT without a decrease of VE-cadherin has been reported by others, ${ }^{17}$ findings of the current study do not meet the criteria for EndMT. However, cells that had undergone morphologic change in response to IL- $1 \beta$ or TNF- $\alpha$ became more contractile and migratory. Furthermore, IL- $1 \beta$ and TNF- $\alpha$ rendered the HPAECs resistant to apoptosis in a growth factor-deficient environment. These results suggest that 1) endothelial cells can contribute to 
A

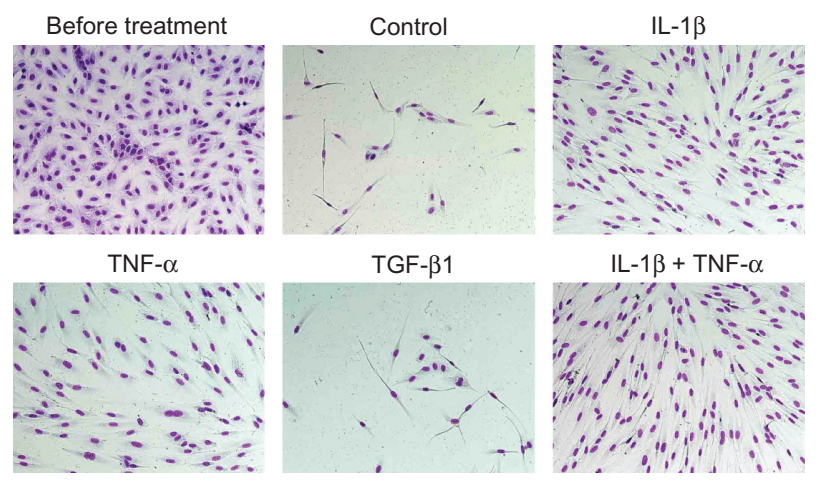

B
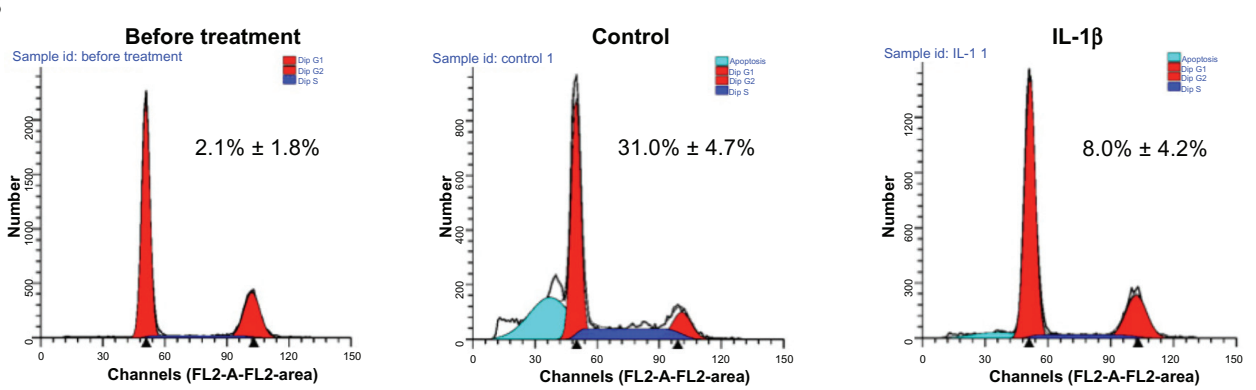

TNF- $\alpha$
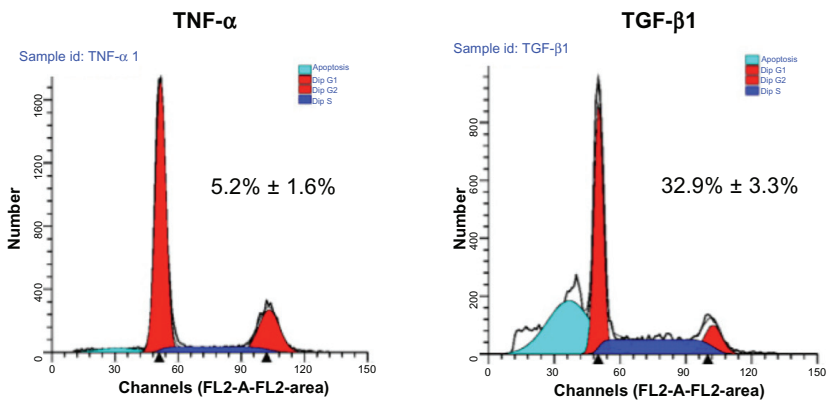

Figure 2 Effect of cytokines on cell survival following withdrawal of growth factors. The subconfluent cells (before treatment, upper left panel) were cultured in serum and growth factor-free medium with or without $2 \mathrm{ng} / \mathrm{mL}$ of cytokines. A) Microscopic observation after 5 days of treatment. The cells remaining attached to the culture dish were fixed, stained, and photographed (original magnification $\times 200$ ). B) Profiling of DNA contents after 2 days of treatment. Both floating and attached cells were collected and DNA content was profiled by FACS analysis. FACS tracings are from a single experiment. Insert: Percentage of apoptotic cells. Values are means \pm SD of 3 separate experiments. Note: $* P<0.01$ compared with control.

tissue repair/remodeling without undergoing "EndMT", 2) inflammatory cytokine induced tissue repair may include modulating endothelial cell viability, migration and remodeling of extracellular matrix, and 3) acquired apoptosis-resistant phenotype may be a mechanism by which endothelial cells can survive in an injured area to contribute to tissue repair/ remodeling.

TGF- $\beta 1$ has been reported to be a major inducer of epithelial-mesenchymal transition (EMT) in a variety of epithelial cells. ${ }^{11,12,18}$ TGF- $\beta 1$ can also induce EndMT in certain endothelial cells. ${ }^{14,17}$ In the present study, however, TGF- $\beta 1$ did not affect HPAEC morphology, migration, or contractility of collagen gels. This phenomenon is unlikely due to lack of activity of TGF- $\beta 1$ in that the same concentration of TGF- $\beta 1$ could induce EMT in A549 cells and augment collagen gel contraction by lung fibroblasts, which were reported previously. ${ }^{3,11,12}$ Multiple mechanisms may be account for the different effect of TGF- $\beta 1$ in endothelial cells. First, it might be due to relatively lower expression of TGF- $\beta$ receptors in HPAEC as evidenced by immunoblot (data not shown). Second, expression of endogenous inhibitors of Smad pathway signaling, for instance, Smad 7, could render cells resistant to TGF- $\beta 1$. Third, endothelial cells may lack required cofactors. In this regard, Hashimoto et al have recently reported that combined treatment of Ras and TGF- $\beta$ could induce EndMT in pulmonary microvascular endothelial cells, ${ }^{16}$ suggesting some cofactors may be required for TGF$\beta$-induced EndMT in certain endothelial cells. 
A
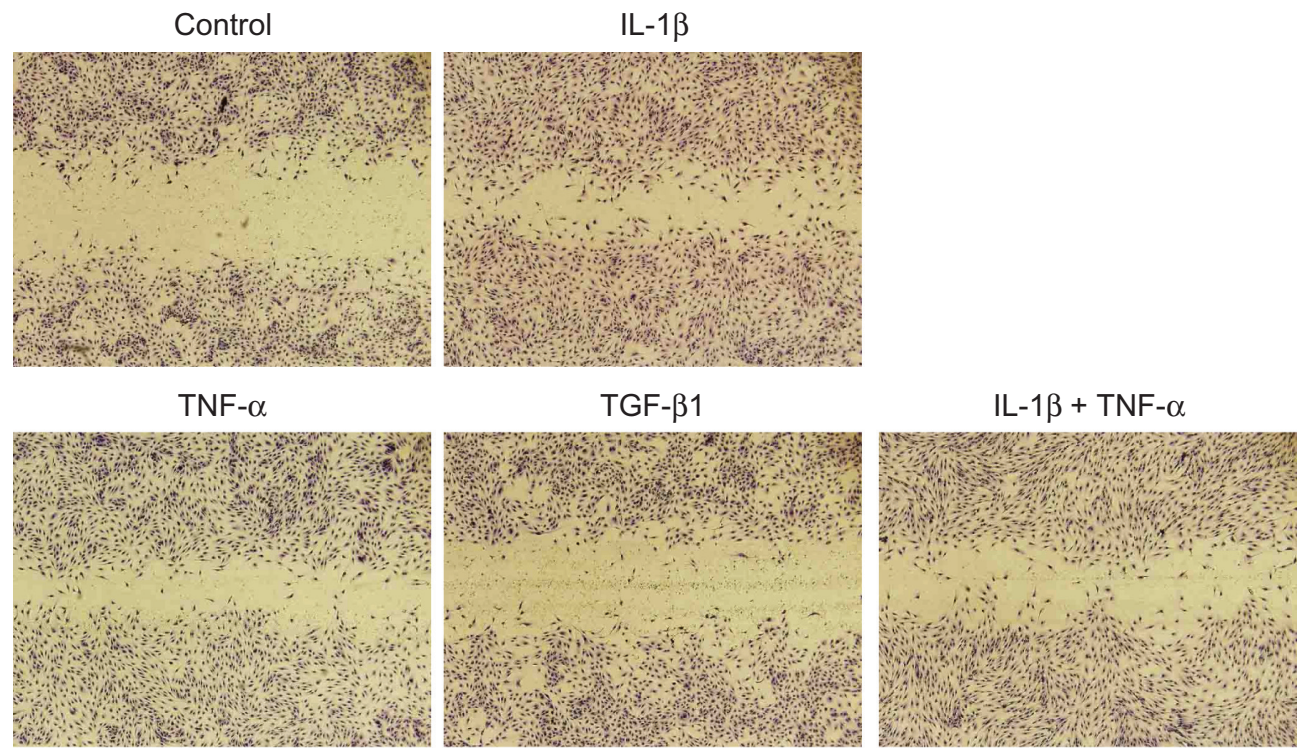

B

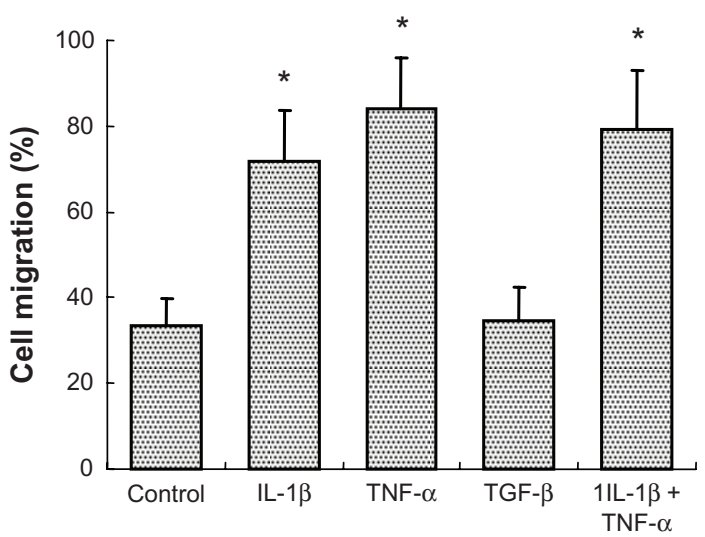

C

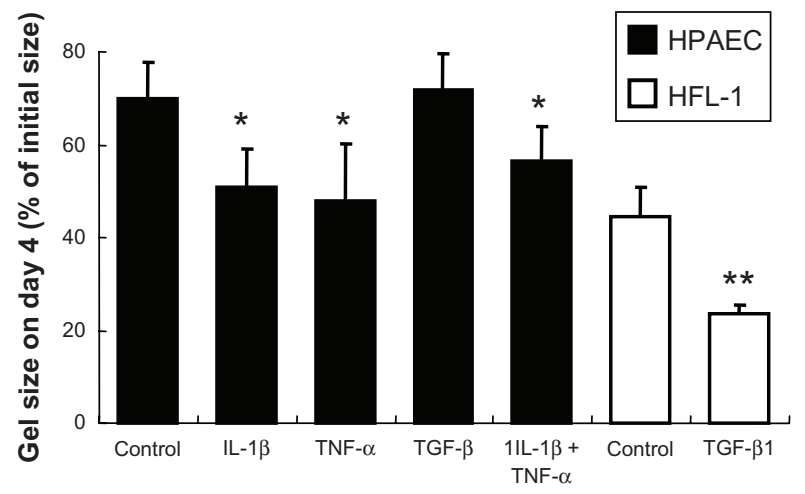

Figure 3 Effect of cytokines on wound closure and gel contraction. A) Microscopic observation of wound closure assay. Cells were treated with $2 \mathrm{ng} / \mathrm{mL}$ of cytokines for 2 days. After wounding, cells were incubated for 16 hours followed by microphotography as shown (original magnification $\times 40$ ). B) Quantification of wound closure assay. Cell migration was quantified by counting migrated area at 0 and 16 hours after wounding. Data presented are means \pm SD of 3 separate experiments. C) Gel contraction assay. HPAECs and human fetal lung fibroblasts (HFL-I) were cast into collagen gels (day 0 ) and treated with or without 2 ng/mL of cytokines for 4 days. Vertical axis: gel size expressed as percent of initial size (\%). Data presented are means \pm SD of 3 separate experiments.

Notes: $* p<0.05$ compared with control; $* * p<0.01$ compared with control.

In the current study, we demonstrated the involvement of the NF- $\kappa B$ signaling pathway in cellular responses induced by IL- $1 \beta$ or TNF- $\alpha$. Consistent with previous reports, ${ }^{1,8,9}$ IL- $1 \beta$ and TNF- $\alpha$ activated NF- $\kappa$ B signaling as evidenced by induction of phosphorylated-p65 (data not shown). More importantly, siRNA targeting p65 blocked the effect of morphologic alteration, cell survival, cell migration, and contraction of collagen gels induced by IL- $1 \beta$ - and TNF- $\alpha$. These findings suggest that NF- $\kappa B$ p 65 activation in response to IL- $1 \beta$ or TNF- $\alpha$ is essential for HPAEC functions related to tissue repair/remodeling.

Besides lack of change in endothelial and mesenchymal cell markers in HPAECs treated with IL- $1 \beta$ or TNF- $\alpha$, there are several differences between fibroblast-like spindle-shaped
HPAECs and "real" lung fibroblasts directly derived from embryonic mesenchymal cells. First, fibroblasts grow well in $10 \%$ FBS-DMEM, while fibroblast-like spindle-shaped HPAECs were not able to survive in this medium (data not shown). Second, following removal of the cytokines, fibroblast-like HPAEC morphology reverted to the polygonal endothelial morphology. Even if HPAECs were exposed to the cytokines in the longer term (up to 14 days), none of these fibroblast phenotypes were induced except for spindleshaped morphology. Incomplete fibroblast-like functions and reversible phenotypic alteration in endothelial cells might be important for angiogenesis.

Apoptosis, programmed cell death, is a major mechanism by which cells are removed from tissues. Apoptosis can be 
A

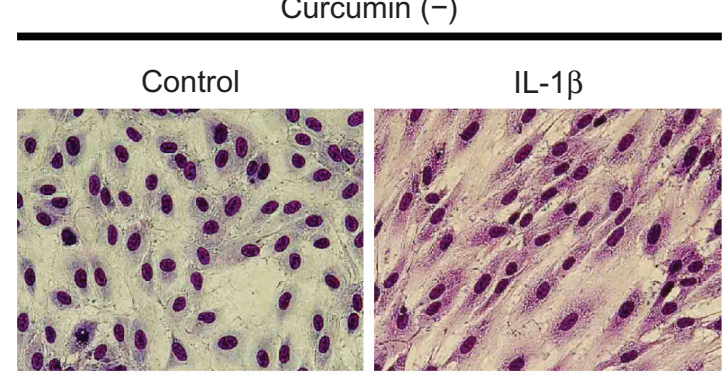

TNF- $\alpha$

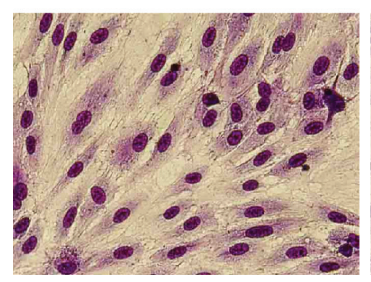

$\mathrm{IL}-1 \beta+\mathrm{TNF}-\alpha$

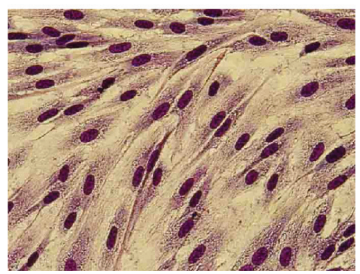

Curcumin (+)

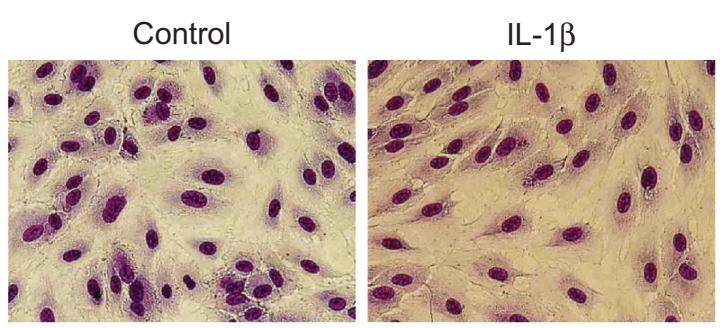

TNF- $\alpha$

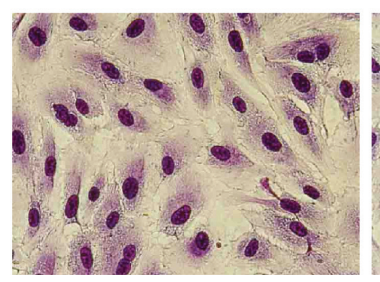

$\mathrm{IL}-1 \beta+\mathrm{TNF}-\alpha$

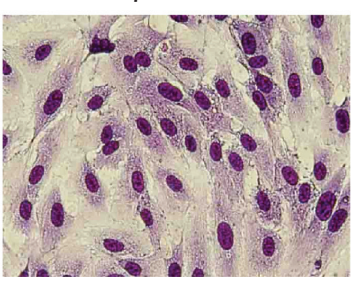

B

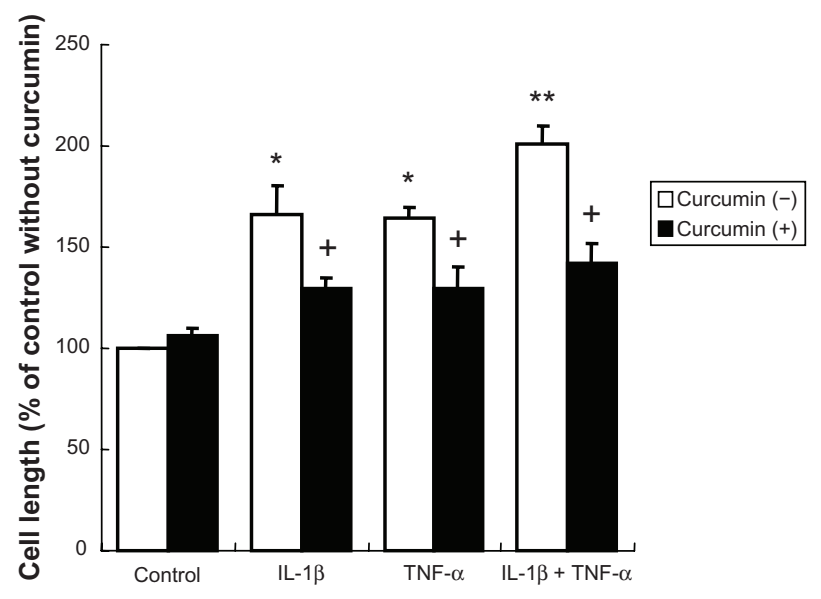

C

Curcumin (-)

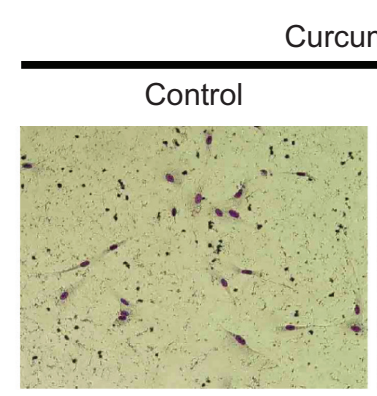

Curcumin $(+)$

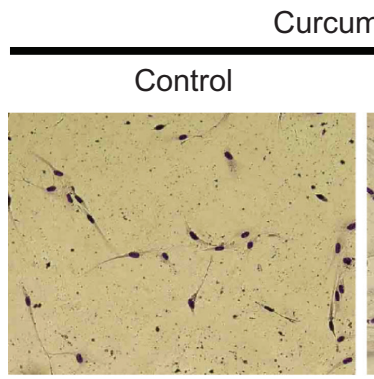

IL-1 $1 \beta$

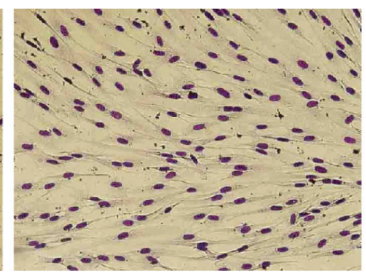

$\mathrm{IL}-1 \beta+\mathrm{TNF}-\alpha$
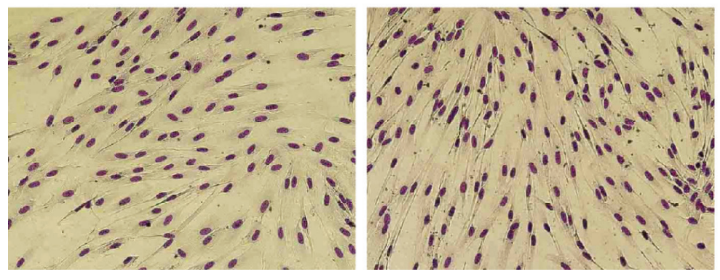

TNF- $\alpha$

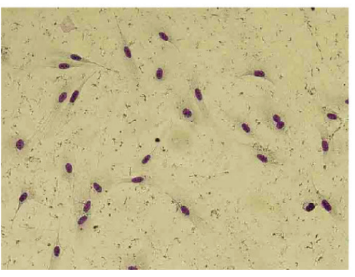

$\mathrm{IL}-1 \beta+\mathrm{TNF}-\alpha$

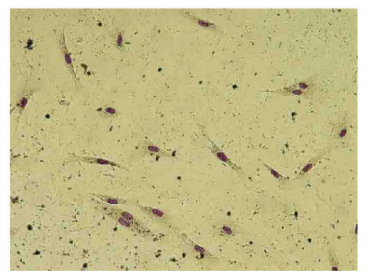

Figure 4 Effect of NF-kB inhibitor on cell morphology and cell survival. A) Cell morphology. Cells were cultured in presence or absence of curcumin (I0 $\mu$ M) for 2 days (original magnification $\times 400$ ). B) Cell length. Values are means \pm SD of 3 separate experiments. C) Cell survival. Subconfluent cells were cultured with or without curcumin in serum and growth factors free medium for 5 days.

Notes: $* P<0.05$ compared with control; $* * P<0.05$ compared with cells treated with IL-I $\beta ;+P<0.05$ compared to same cytokine treatment without curcumin. 
A

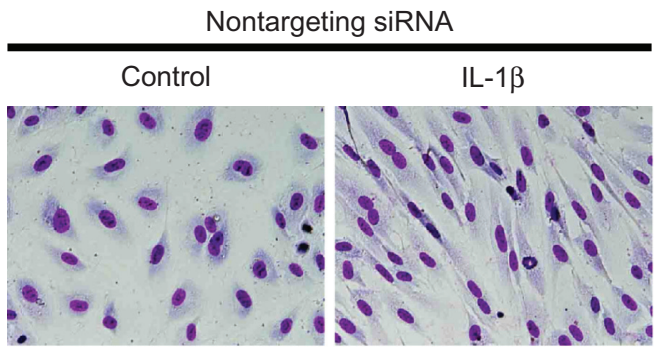

TNF- $\alpha$

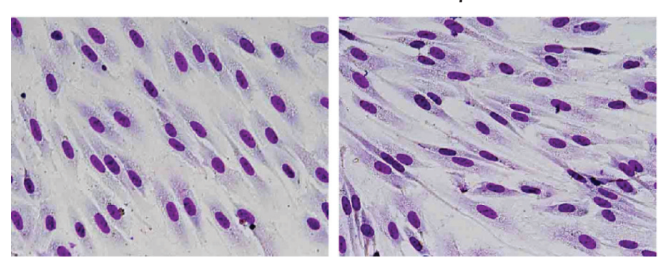

siRNA targeting NF-кB p65

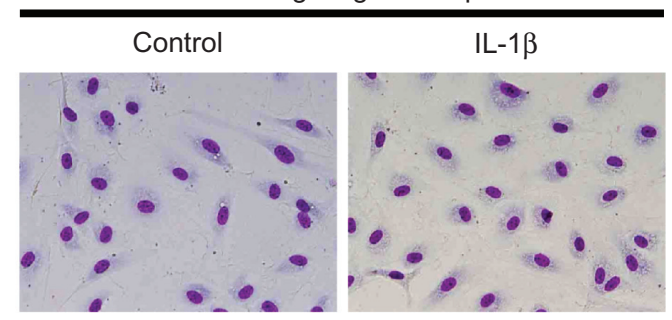

TNF- $\alpha$

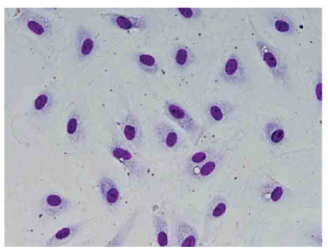

$\mathrm{IL}-1 \beta+\mathrm{TNF}-\alpha$

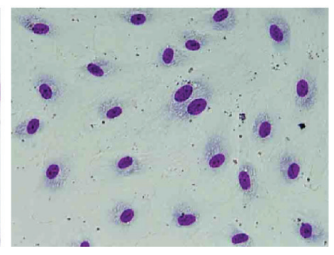

B

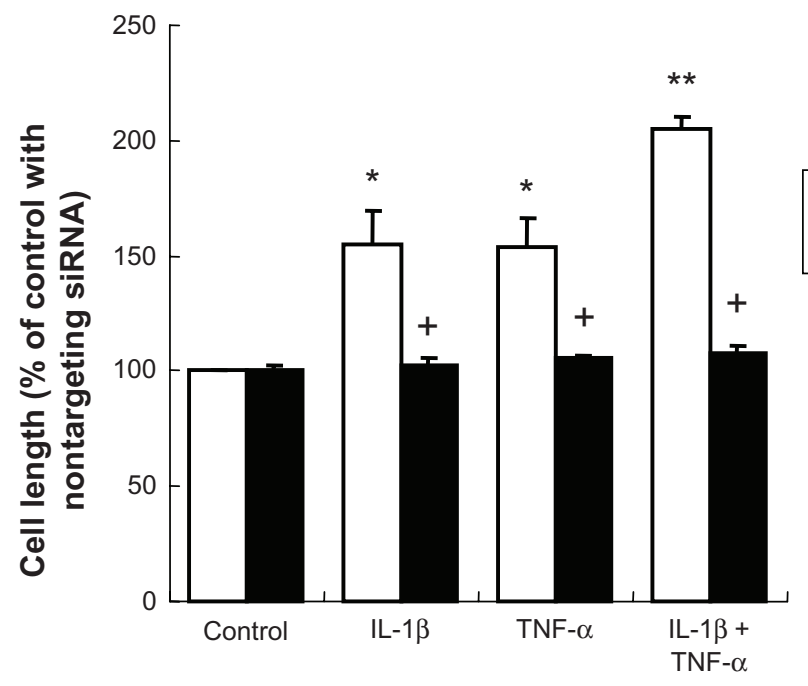

C

Nontargeting siRNA

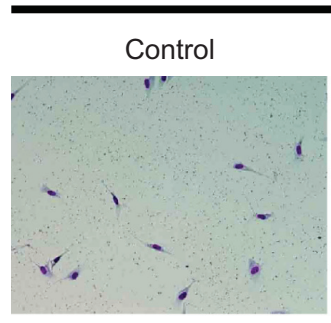

TNF- $\alpha$

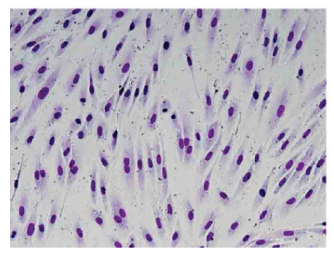

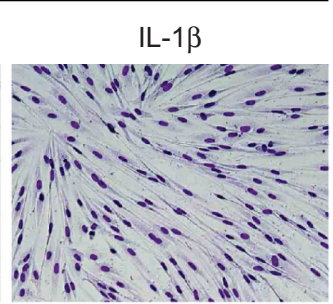

$\mathrm{IL}-1 \beta+\mathrm{TNF}-\alpha$

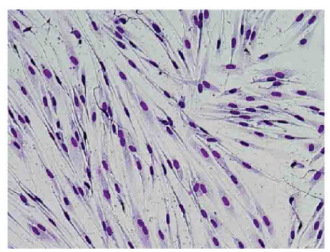

siRNA targeting NF-кB p65

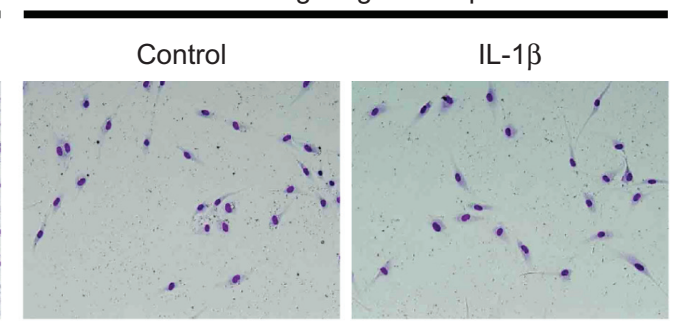

TNF- $\alpha$

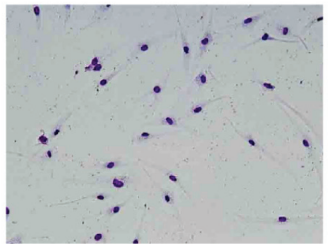

$\mathrm{IL}-1 \beta+\mathrm{TNF}-\alpha$

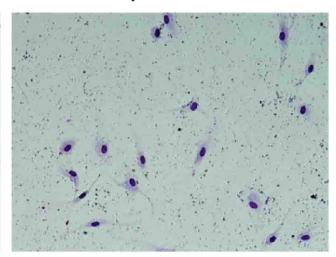

Figure 5 Effect of suppression of NF-kB p65 by siRNA on cell morphology and cell survival. A) Cell morphology. After RNA interference, cells were treated with $2 \mathrm{ng} / \mathrm{mL}$ cytokines for 2 days (original magnification $\times 400$ ). B) Cell length. Values are means \pm SD of 3 separate experiments. C) Cell survival. After RNA interference, cells were treated with $2 \mathrm{ng} / \mathrm{mL}$ cytokines in serum and growth factor-free medium for 4 days (original magnification $\times 200$ ).

Notes: $* P<0.05$ compared with control; $* * P<0.05$ compared with cells treated with IL-I $\beta ;+P<0.05$ compared with same cytokine treatment transfected with nontargeting siRNA. 
A

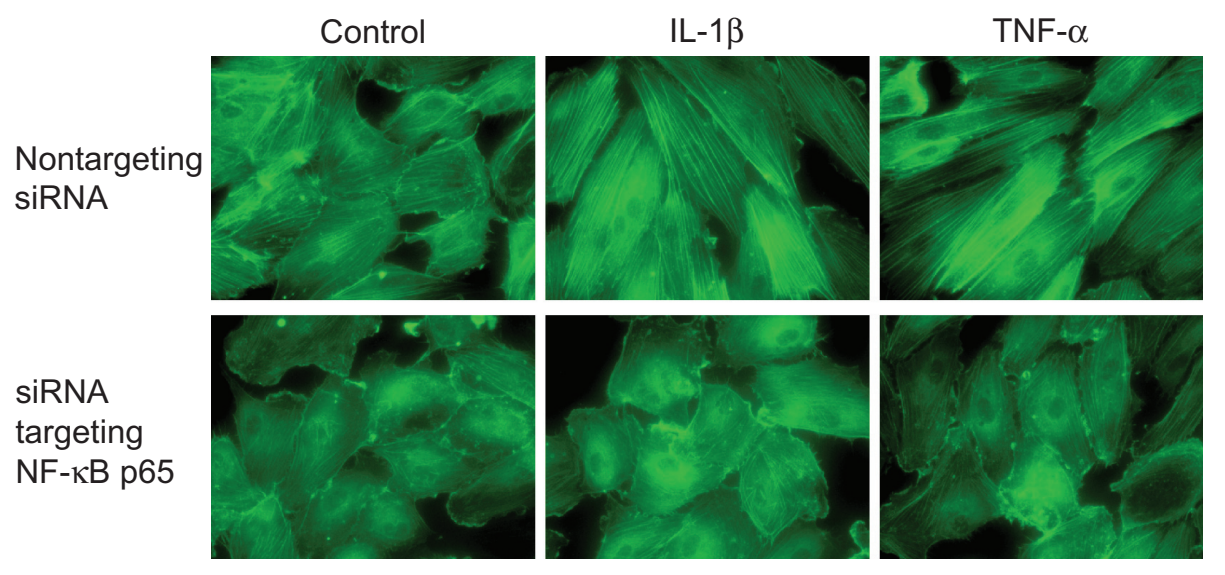

B

Nontargeting siRNA

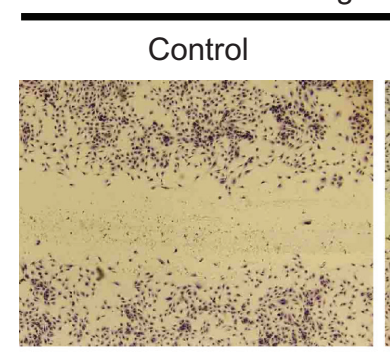

TNF- $\alpha$

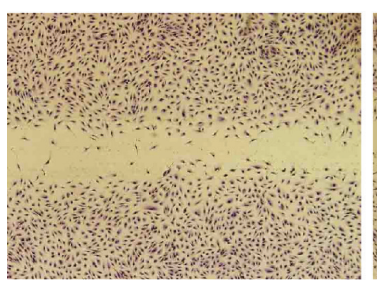

$\mathrm{IL}-1 \beta+\mathrm{TNF}-\alpha$

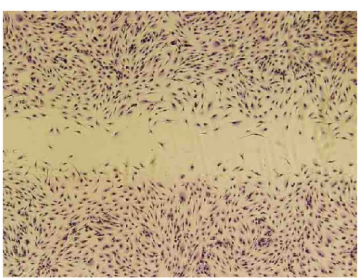

siRNA targeting NF-кB p65

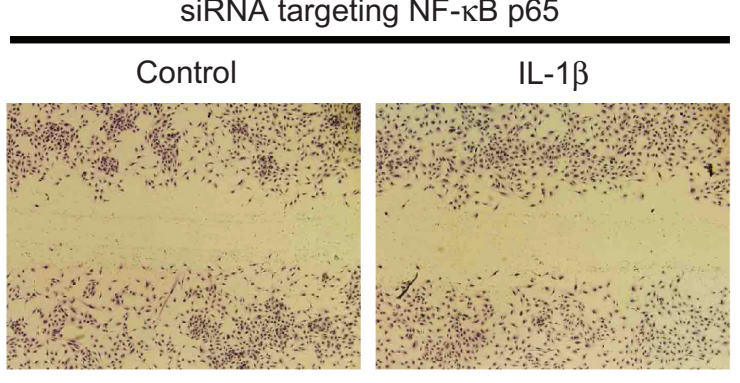

TNF- $\alpha$

$\mathrm{IL}-1 \beta+\mathrm{TNF}-\alpha$

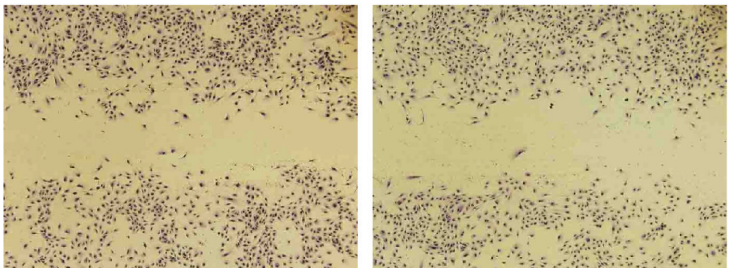

C

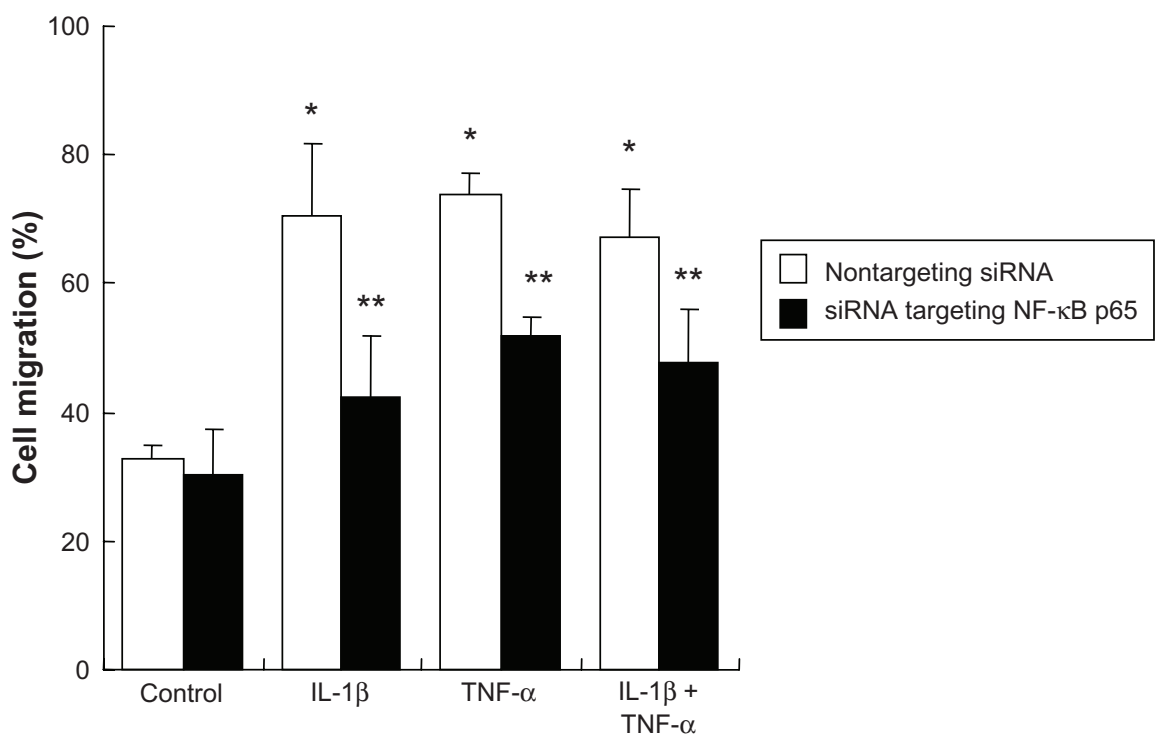

Figure 6 (Continued) 
D

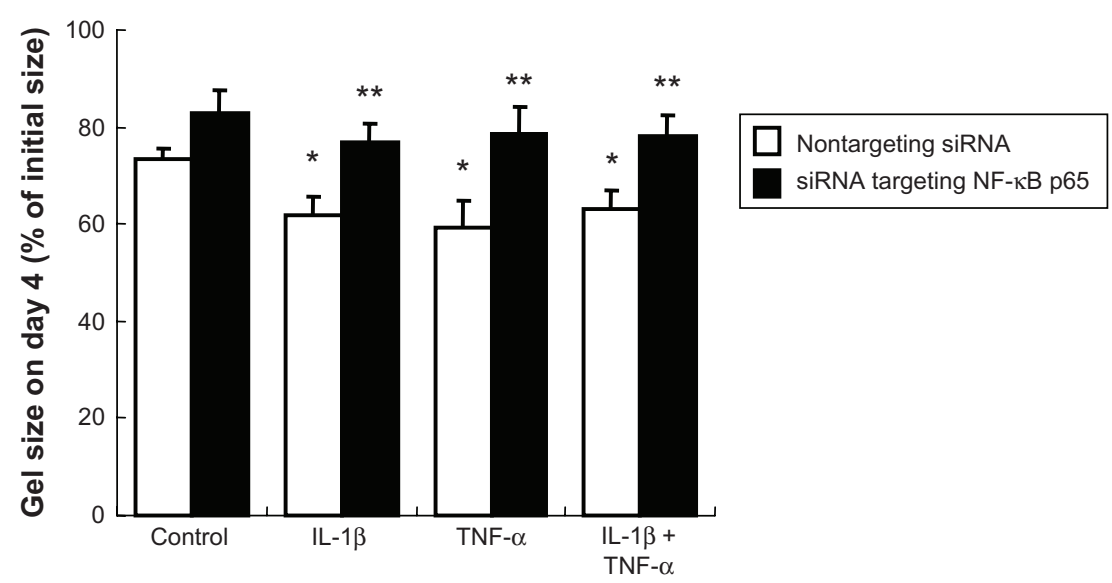

Figure 6 Effect of suppression of NF-KB p65 by siRNA on actin organization, cell migration, and gel contraction. After RNA interference, cells were treated with cytokines. A) Actin microfilaments. B) Wound closure assay. After RNA interference, cells were wounded and cultured in the presence or absence of cytokines for 16 hours. C) Quantification of wound closure assay. Data presented are means \pm SD of 3 separate experiments. D) Gel contraction assay. After RNA interference, cells were cast into collagen gels and cultured in the presence or absence of cytokines for 4 days. Data presented are means \pm SD of 3 separate experiments.

Notes: $* P<0.05$ compared with control transfected with nontargeting control siRNA; $* * P<0.05$ compared with same cytokine treatment transfected with nontargeting control siRNA.

triggered by a variety of stimuli including inflammatory cytokines. In this regard, both IL-1 $\beta$ and TNF- $\alpha$ are known to induce apoptosis in several cell types including airway epithelial cells and fibroblasts and microvascular endothelial cells. ${ }^{19-21}$ In contrast to these reports, here we report that IL-1 $\beta$ and TNF- $\alpha$ not only protected HPAECs from undergoing apoptosis in response to withdrawal of growth factors and serum, but also induced HAPECs to undergo morphologic alteration. This suggests that cells undergoing fibroblast-like morphologic change may activate a mechanism by which cells can survive in an injured area and may contribute to tissue repair or fibrosis. This also suggests that pulmonary artery endothelial cells may be involved in the pathogenesis of respiratory diseases such as pulmonary hypertension and fibrosis through a mechanism of extended survival and fibroblast-like alteration following airway inflammation. Therefore, pulmonary endothelial cells might also be a therapeutic target for diseases including pulmonary hypertension and lung fibrosis.

\section{Conclusion}

IL-1 $\beta$ and TNF- $\alpha$, but not TGF- $\beta 1$, induce HPAEC to undergo morphologic alteration from a polygonal shape to spindle-shaped fibroblast-like cells. IL-1 $\beta$ and TNF- $\alpha$, but not TGF- $\beta 1$, prevent cells from apoptosis induced by the absence of serum and growth factors, stimulate migration, and augment contraction of collagen gels. The NF- $\kappa B$ signaling pathway mediates all these effects of IL- $1 \beta$ and TNF- $\alpha$ on HPAEC. These findings suggest that endothelial cells, in response to inflammatory cytokines, may contribute to tissue repair/remodeling and, possibly, to pathologic tissue alterations.

\section{Abbreviations}

EBM, endothelial cell basal medium; EGM, endothelial cell growth medium; EMT, epithelial-mesenchymal transition; EndMT, endothelial-mesenchymal transition; FBS, fetal bovine serum; HPAEC, human pulmonary artery endothelial cell; HUVEC, human umbilical vein endothelial cells; IL, interleukin; NF, nuclear factor; TGF, transforming growth factor; TNF, tumor necrosis factor; siRNA, small interfering RNA.

\section{Acknowledgment}

The authors thank Ms Lillian Richards for the excellent secretarial support of this manuscript.

\section{Disclosure}

The authors report no conflicts of interest.

\section{References}

1. Saklatvala J, Davis W, Guesdon F. Interleukin 1 (IL1) and tumour necrosis factor (TNF) signal transduction. Philos Trans $R$ Soc Lond B Biol Sci. 1996;351(1336):151-157.

2. Chaudhuri V, Zhou L, Karasek M. Inflammatory cytokines induce the transformation of human dermal microvascular endothelial cells into myofibroblasts: a potential role in skin fibrogenesis. J Cutan Pathol. 2007;34(2):146-153 
3. Kobayashi T, Liu X, Kim HJ, et al. TGF-beta1 and serum both stimulate contraction but differentially affect apoptosis in 3D collagen gels. Respir Res. 2005;6:141.

4. Sugiura H, Liu X, Duan F, et al. Cultured lung fibroblasts from ovalbumin-challenged "asthmatic" mice differ functionally from normal. Am J Respir Cell Mol Biol. 2007;37(4):424-430.

5. Zhu YK, Liu X. Skold MC, et al. Cytokine inhibition of fibroblastinduced gel contraction is mediated by PGE(2) and NO acting through separate parallel pathways. Am J Respir Cell Mol Biol. 2001;25(2):245-253.

6. Shupp-Byrne DE, Church RL. "Embryonic" collagen (type I trimer) alpha 1-chains are genetically distinct from type I collagens alpha 1-chains. Coll Relat Res. 1982;2(6):481-494.

7. Sugiura H, Liu X, Kobayashi T, et al. Reactive nitrogen species augment fibroblast-mediated collagen gel contraction, mediator production, and chemotaxis. Am J Respir Cell Mol Biol. 2006;34(5):592-599.

8. Wu JT, Kral JG. The NF-kappaB/IkappaB signaling system: a molecular target in breast cancer therapy. J Surg Res. 2005;123(1):158-169.

9. Huber MA, Azoitei N, Baumann B, et al. NF-kappaB is essential for epithelial-mesenchymal transition and metastasis in a model of breast cancer progression. J Clin Invest. 2004;114(4):569-581.

10. Tabruyn SP, Griffioen AW. NF-kappaB: a new player in angiostatic therapy. Angiogenesis. 2008;11(1):101-106.

11. Kasai H, Allen JT, Mason RM, Kamimura T, Zhang Z. TGF-beta1 induces human alveolar epithelial to mesenchymal cell transition (EMT). Respir Res. 2005;6:56.

12. Liu X. Inflammatory cytokines augments TGF-beta1-induced epithelialmesenchymal transition in A549 cells by up-regulating TbetaR-I. Cell Motil Cytoskeleton. 2008;65(12):935-944.
13. Hess DC, Thompson Y, Sprinkle A, Carroll J, Smith J. E-selectin expression on human brain microvascular endothelial cells. Neurosci Lett. 1996;213(1):37-40.

14. Zeisberg EM, Tarnavski O, Zeisberg M, et al. Endothelial-tomesenchymal transition contributes to cardiac fibrosis. Nat Med. 2007;13(8):952-961.

15. Arciniegas E, Frid MG, Douglas IS, Stenmark KR. Perspectives on endothelial-to-mesenchymal transition: potential contribution to vascular remodeling in chronic pulmonary hypertension. Am J Physiol Lung Cell Mol Physiol. 2007;293(1):L1-L8.

16. Hashimoto N, Phan SH, Imazumi K, et al. Endothelial-mesenchymal transition in bleomycin-induced pulmonary fibrosis. Am J Respir Cell Mol Biol. 2009;43(2):161-172.

17. Kokudo T, Suzuki Y, Yoshimatsu Y, et al. Snail is required for TGF betainduced endothelial-mesenchymal transition of embryonic stem cellderived endothelial cells. J Cell Sci. 2008;121(Pt 20):3317-3324.

18. Willis BC, Liebler JM, Luby-Phelps K, et al. Induction of epithelialmesenchymal transition in alveolar epithelial cells by transforming growth factor-beta1: potential role in idiopathic pulmonary fibrosis. Am J Pathol. 2005;166(5):1321-1332.

19. Okada M, Sugita K, Inukai T, et al. Hepatocyte growth factor protects small airway epithelial cells from apoptosis induced by tumor necrosis factor-alpha or oxidative stress. Pediatr Res. 2004;56(3):336-344.

20. Nakamura M, Matute-Bello G, Liles WC, et al. Differential response of human lung epithelial cells to fas-induced apoptosis. Am J Pathol. 2004;164(6):1949-1958.

21. Kaur H, Chaurasia SS, Agrawal V, Suto C, Wilson SE. Corneal myofibroblast viability: opposing effects of IL-1 and TGF beta1. Exp Eye Res. 2009;89(2):152-158.

\section{Publish your work in this journal}

The Journal of Inflammation Research is an international, peer-reviewed open-access journal that welcomes laboratory and clinical findings on the molecular basis, cell biology and pharmacology of inflammation including original research, reviews, symposium reports, hypothesis formation and commentaries on: acute/chronic inflammation; mediators of inflamma-

\section{Dovepress}

tion; cellular processes; molecular mechanisms; pharmacology and novel anti-inflammatory drugs; clinical conditions involving inflammation. The manuscript management system is completely online and includes a very quick and fair peer-review system. Visit http://www.dovepress.com/ testimonials.php to read real quotes from published authors. 